NBER WORKING PAPER SERIES

\title{
GOLDEN YEARS OR FINANCIAL FEARS? DECISION MAKING AFTER RETIREMENT SEMINARS
}

Steven G. Allen

Robert L. Clark

Jennifer Maki

Melinda Sandler Morrill

Working Paper 19231

http://www.nber.org/papers/w19231

\author{
NATIONAL BUREAU OF ECONOMIC RESEARCH \\ 1050 Massachusetts Avenue \\ Cambridge, MA 02138 \\ July 2013
}

This research was supported by a grant from the FINRA Investor Education Foundation. All results, interpretations and conclusions expressed are those of the author(s) alone, and do not necessarily represent the views of the FINRA Investor Education Foundation or any of its affiliated companies. No portion of this work may be reproduced, cited, or circulated without the express written permission of the author(s). The views expressed herein are those of the authors and do not necessarily reflect the views of the National Bureau of Economic Research.

NBER working papers are circulated for discussion and comment purposes. They have not been peerreviewed or been subject to the review by the NBER Board of Directors that accompanies official NBER publications.

(C) 2013 by Steven G. Allen, Robert L. Clark, Jennifer Maki, and Melinda Sandler Morrill. All rights reserved. Short sections of text, not to exceed two paragraphs, may be quoted without explicit permission provided that full credit, including $(\subset$ notice, is given to the source. 
Golden Years or Financial Fears? Decision Making After Retirement Seminars

Steven G. Allen, Robert L. Clark, Jennifer Maki, and Melinda Sandler Morrill

NBER Working Paper No. 19231

July 2013

JEL No. J14,J26,J32

\section{ABSTRACT}

Many organizations provide retirement planning seminars to their employees as a benefit to help them make better informed retirement decisions. This study examines the participants in 85 seminars conducted by five companies in 2008 and 2009 to determine how much learning takes place and whether employees adjust retirement plans. Using surveys conducted before and after the seminars, we find that financial literacy and knowledge of retirement program parameters are significantly higher after the seminar. Employees with the largest increases in knowledge were most likely to change their planned retirement age and planned age of claiming Social Security benefits.

Steven G. Allen

Jenkins Graduate School of Management

NC State University

2124 Nelson Hall

P.O.Box 7229

Raleigh, NC 27695-7229

and NBER

steve_allen@ncsu.edu

Robert L. Clark

Poole College of Management

Box 7229

North Carolina State University

Raleigh, NC 27695

and NBER

robert_clark@ncsu.edu
Jennifer Maki

Center for Healthcare Economics \& Policy

FTI Consulting

1101 K Street

NW Suite B100

Washington, DC 20005

jamaki@ncsu.edu

Melinda Sandler Morrill

Department of Economics

North Carolina State University

Box 8110

Raleigh, NC 27695-8110

melinda_morrill@ncsu.edu 


\section{Introduction}

As retirement approaches, an older worker faces a series of important and irreversible choices including when to retire from her current job and when to start collecting Social Security. These decisions have become much more complicated as defined contribution plans largely replaced defined benefit plans and as financial options facing investors become more complex. These actions will strongly affect individuals' income levels in retirement, the sensitivity of income to economic fluctuations, and the ability to maintain consumption throughout retirement.

To make the transition into retirement successfully, workers must rely on their financial knowledge and obtain information about retirement programs offered by employers and the government. Without accurate information and sufficient financial literacy, some older workers will make suboptimal employment and investment choices that will have adverse consequences. Most lifecycle models of economic behavior assume that individuals have basic financial literacy and make resource allocation decisions to develop saving/consumption plans along with work/retirement choices to maximize lifetime utility.

Economists and other social science researchers have recently examined the level of financial literacy and its role in economic decision making. The general conclusion of this research, recently surveyed by Hastings, Madrian and Skimmyhorn (2012), is that individuals have quite low levels of financial literacy. This would make them more likely to make suboptimal resource allocation decisions. Individuals with low levels of financial literacy have difficulty with paying bills on time, saving, and diversifying, as shown in the many research studies cited by Hastings et al. Low levels of financial literacy are also associated with lower 
wealth (see Lusardi and Mitchell, 2007, 2011; Gustman, Steinmeir and Tabatabai, 2012; van Rooij, Lusardi and Alessie, 2012).

This paper addresses two key questions. First, can financial literacy programs increase knowledge? And second, if steps are taken to increase financial literacy and pension understanding, will there be changes in retirement plans? While it is interesting to see an association between low literacy levels and certain types of decisions, this does not necessarily imply that improving financial literacy will lead to a revision in retirement plans. Low literacy levels could reflect other variables (such as intelligence, attitudes, or preferences) that do not show up in household surveys but more truly determine choices. A few studies have attempted to determine whether changes in knowledge base can lead to changes in decisions. For instance, Liebman and Luttmer (2011) conducted a field experiment where a sample of older workers received information about Social Security provisions in the mail; these workers were 4 percentage points more likely than the control group to be in the labor force one year later.

Financial literacy programs can take many forms and can occur in many different settings. This study focuses on financial education and retirement planning programs in the workplace. Since individuals spend substantial time at work and since much of what they need to know to develop retirement plans is related to employer-provided benefits, the workplace is well-suited for financial education programs. The programs that we have studied are provided by the employer at no cost to the employee and are conducted during the workday on company time.

In this study, we examine the retirement planning programs offered by employers to their older employees and assess their impact on financial literacy and retirement plans. There is a sizable literature on retirement planning (recent examples include Benitez-Silva and Dwyer, 
2005, and Chan and Stevens, 2008) and the choice of when to claim Social Security benefits (see Behaghel and Blau, 2012, and references therein), but the role of financial literacy is underexplored. A related literature finds that those with access to seminars save more and have higher wealth (e.g., Bayer, Bernheim, and Scholz, 2009; Bernheim and Garrett, 2003; Lusardi, 2005), but does not explicitly consider how seminars alter retirement plans.

We study how worker knowledge changes after completion of a retirement seminar and whether the changes in knowledge actually lead to changes in retirement plans. We build upon previous work by Clark, Morrill and Allen (2012a, 2012b) that examined retirement plans of workers in three companies that did not have retirement planning seminars. That study finds employees who mistakenly think that Social Security or pension eligibility is later than it really is plan to retire later than well informed workers. The results are more mixed for those who mistakenly thought they were eligible earlier than they really were; this type of mistake on full Social Security benefit eligibility is associated with earlier retirement whereas mistakes regarding early Social Security eligibility and private pension eligibility were unrelated to planned retirement age.

This paper demonstrates an increase in employees' knowledge about pension plan parameters and financial matters resulting from attending a pre-retirement planning workshop. We then explore whether attendees make changes in their plans for retirement and receipt of Social Security benefits. Our findings indicate that participants increase their financial and pension literacy, and on the basis of new knowledge many alter their retirement plans.

\section{Financial Literacy and Retirement Decisions}

When individuals enter the labor force, they immediately begin making important choices about their lifetime consumption and saving profiles. Lifecycle theory suggests that individuals 
set retirement goals and targets early in their careers. In order to achieve these retirement goals, workers select labor supply, saving and investment behavior consistent with their goals. As new information becomes available, people will re-optimize their consumption and saving patterns, and they may alter their retirement expectations using this new knowledge. The primary retirement goals that workers must set include the age of retirement and their levels of retirement income. A fundamental principle in retirement planning is that younger retirement ages and higher retirement incomes require more saving and less consumption throughout one's working life. Younger retirement ages may require more risk-taking as well.

While considerable attention has been paid to the undersaving of American workers, much less attention has been focused on how older workers make decisions concerning the allocation of their resources as they enter into retirement. Workers must decide when and how to enter into retirement, and how to best use the resources available to them. Limited available evidence suggests that older workers do not have sufficient financial literacy needed to make the many choices that must be made as they transition from work to retirement (Bernheim 1995, 1998; Hilgert and Hogarth 2002; Lusardi and Mitchell 2006, 2007). Incorrect or insufficient knowledge can lead to suboptimal choices. For this reason, programs that increase financial literacy and retirement program knowledge have the potential to improve retirement decisions and produce better retirement outcomes (Clark and d'Ambrosio 2003; Clark, et al., 2006; Lusardi 2008). Pre-retirement planning seminars held in the workplace can efficiently address the numerous questions that individuals approaching retirement share, thereby reducing human resources costs.

Some of the most important decisions older workers must make include: (1) What age to retire from a career jobs? (2) When retiring from a career job, whether to request a lump sum 
distribution from a defined benefit plan or accept a life annuity from the plan? (3) What age to start receiving Social Security benefits? (4) Whether to annuitize the account balances in a 401(k) plan? In making these important decisions, individuals must rely on their own financial literacy and understanding of financial mathematics and have accurate knowledge about their employers' and national retirement programs. Workers can acquire the needed knowledge to make these key decisions in various ways, and one resource often available is employersponsored pre-retirement planning programs.

Many large employers offer some type of planning seminar for retirement eligible employees. Sabelhaus, Brogdan, and Holden (2008) report that 46 percent of pension participants covered by defined contribution plans work for companies that provide resources to assist participants in retirement choices. Thirty percent of participants have the opportunity to attend employer seminars and workshops, and almost 85 percent of these attendees rely on this information to 'some' or a 'great' extent in making their retirement decisions. In a plan sponsor survey, Wray (2008) finds that 31 percent of employers offer seminars focusing on retirement assets and income planning. While not universal, employer-provided retirement planning programs are common, accessible to perhaps one-third of the labor force.

Although many business leaders and analysts believe these programs are beneficial to employees and increase their financial knowledge, relatively little formal analysis of employer programs has been conducted. Thus, not much is known about the effectiveness of workplace education and its ability to alter the retirement decisions of employees. To address these important issues, we examined the pre-retirement programs of five large national employers. The principal objective of the research is to assess whether these programs are successful in 
improving workers' knowledge as they approach retirement. We also examine whether, on the basis of participating in a workplace educational event, employees alter their retirement plans.

\section{Research Methodology}

To evaluate employer-provided pre-retirement planning programs, we assembled a team of five large employers ranging in size from 8,000 to 40,000 employees. Four of the firms have sites throughout the United States; their home offices are in New Jersey, North Carolina, Oklahoma, and Washington. Each of the employers offers defined benefit plans (three employers have cash balance plans), each offers health insurance to active and retired workers, and each offers supplemental defined contribution plans (all but one have an employer match). The employee populations of these companies vary by gender, education, earnings, and geographic location.

We worked with each employer in the spring of 2008 to develop an evaluation process for their pre-retirement planning programs. Our methodology included the development of two surveys. The first survey was to be completed by each participant prior to the start of the program. The objective was to obtain baseline socioeconomic data about the individual and his/her household, as well as information concerning retirement plans and investment strategies. Employees also answered questions about their financial literacy and their knowledge of employer and national retirement programs, described in detail in Section IV.

At the conclusion of the seminar, participants were asked to complete a second survey. This time, participants answered additional questions concerning the program, the employee's assessment of the seminar, and its value. The knowledge and literacy questions were repeated, to see if the participants' overall knowledge of retirement programs and financial markets had improved. Seminar participants were also again asked about their retirement plans, so we can observe any changes in plans that individuals made due to the seminar. Three of the employers 
used hard-copy surveys. The program leaders at each of these companies extended the length of their programs to allow participants 15 to 20 minutes prior to the start of the seminar to complete Survey One and similar time at the end of the program to complete Survey Two. The other two employers used electronic surveys; in this case, a link to the electronic Survey One was sent via email to participants about a week prior to the seminar and a link to Survey Two was e-mailed to the participants immediately following the seminar. Attendees were given approximately two weeks to complete Survey Two. This research is based on participant surveys from 85 seminars that incorporated our surveys into their programs between June 2008 and December 2009. We merged the responses from the five employers into a single data set which we call Participants Attending Retirement Seminars (PARS). Table 1 presents basic statistics about each employer, their retirement planning seminars, and the sample size in PARS. ${ }^{1}$

\section{[Table 1]}

Seminars varied in scope and duration across the employers. During the research period, Employer A held 31 seminars that were 4 hours long with approximately 500 total attendees. Employer B and Employer E both had all day seminars. Employer D had 12 seminars that were two and half days in duration and covered 281 employees. In 2008, the Employer C seminars were a full day, but in 2009 the seminars were reduced to a half day. Thus, we were able to

${ }^{1}$ We do not conduct analysis at the employer-level and have kept the identities of the employers masked. Although it is interesting to note the similarities and differences among the seminars presented by the employers, with such a small sample of employers one should be cautious about attributing differences observed to differing seminar characteristics with only a limited set of employee control variables. Similarly, although our data do span the start of The Great Recession, because the employers held seminars at different times and the population of attendees may have been affected by the macroeconomic conditions at the time of the seminar, the data are not well suited to a study of the effects of the recent recession on retirement planning. 
develop a unique data set that included seminars ranging in length from one half day to two and half days. Some seminars took place during a significant economic decline and some in the early stages of the economic recovery. ${ }^{2}$ One should therefore be cautious in interpreting any aggregate differences observed between the outcomes at each employer, since many aspects of the seminar, time period, survey, and sample differ. All regression estimates include employer fixed effects, but those are not reported or interpreted as part of the analysis.

During the 18 month data collection period, over 1,500 individuals attended the seminars of these five employers. We received completed responses from 1,182 for a response rate of approximately 76 percent. In the analysis, we restrict the sample to participants with valid responses for age, gender, education, and tenure (dropping 13, 11, 8, and 9 observations, respectively. The sample was restricted to those born between 1943 and 1959, thus participants were approximately age 50 to 65 at the time of the seminars (dropping an additional 39 observations). ${ }^{3}$ We also restrict the sample to those respondents that had a valid response for at least five out of the ten knowledge questions (dropping 34 observations) and who had a valid response for planned retirement age (dropping 228 observations). ${ }^{4}$ The final sample size for our

${ }^{2}$ Goda, Shoven, and Slavov (2012) find a weak negative correlation between the stock market decline in 2008 and planned retirement age, but suggest that the relationship is not driven by wealth shocks.

${ }^{3}$ The age-50 restriction was applied to limit the sample to individuals approaching retirement decisions. Most of the employers only invite retirement eligible employees to these programs so, in fact, this results in only a small number of observations being deleted from the sample. The upper age limit was applied to limit the sample to those who had not yet attained the normal retirement age for Social Security. In addition, we felt that workers over age 65 had already made the decision to delay retirement and that they would most likely have very different responses to these programs than workers age 50 to 65 .

${ }^{4}$ Item non-response for retirement age was high because "don't know" was an allowable response in several versions of the survey. 
analysis is 840 , as shown in Table 1.

We examine the impact of pre-retirement planning programs offered between June 2008 and December 2009. ${ }^{5}$ The usual process followed by the employers is that retirement-eligible employees are invited individually to participate in these programs by their employer: invitations are issued, attendance is tracked, and there are high participation rates. Because of the high demand by employees to participate in the programs, several employers limit participation to once every five years or so. These programs are on-going and the employers expect that over a number of years, most eligible employees will attend one of these programs. Thus, the participants in the programs we observe should roughly reflect the population of older workers at these employers on average.

While our results clearly demonstrate the effectiveness of financial education at the five employers studied, there are two important caveats to the external generalizability of our findings. First, there always is a possibility of selection issues associated with participation in various types of educational events. For example, only workers with certain characteristics might attend these programs. Thus, attendance only by persons who desired to participate could suggest that statistical analysis might overstate the impact of financial education seminars for the population at large. In contrast to past studies of voluntary seminars or benefit fairs, the programs we examine are more structured. While attendance is voluntary, employees receive specific invitations from their employers and attendance is recorded. When questioned, the leaders of the various programs in our study reported to us that nearly all workers invited to participate actually attend the programs and, over time, all retirement eligible workers are invited to attend one of these programs. Therefore, this type of selection bias should be minimal in our

\footnotetext{
${ }^{5}$ At least one of the authors attended a seminar offered by each of the five employers.
} 
study. ${ }^{6}$ Nevertheless, we only observed seminars offered between June 2008 and December 2009 , so it is possible that these programs may have attracted a non-representative sample of the workforce during the 18 months of our project. The leaders of the various employer-provided programs did not report any obvious selection bias among the participants during the study period. The second reason our results may not be generalizable to the full population of workers is that our sample necessarily is employed at larger firms that offer formal pre-retirement planning seminars and have generous pension and retirement benefits. Appendix Table A-1 presents a comparison of our sample (described below) to the nationally representative Health and Retirement Study (HRS) data. As expected our sample has higher levels of education, more years of service, higher earnings, and more financial literacy than the HRS sample.

\section{Survey Design and the PARS Sample}

The basic framework of each of the surveys was similar across the firms; however, some components of the surveys were customized for each employer. The surveys mentioned the specific employer by name, where appropriate, and people were asked about their own employer-specific retirement benefits by name. Questions concerning retirement saving accounts differed somewhat between private-sector versus public/nonprofit employers (i.e., questions concerned 401(k) plans in the private sector and 403(b) and 457 plans in the public sector). In addition, several employers requested that specific questions be added to the survey to help them better understand how their employees were using the human resource programs and accessing the help lines offered by their 401(k) and 403(b) providers.

\footnotetext{
${ }^{6}$ The programs offered by three of the employers have been presented over a number of years. In contrast, the programs by two of the employers were implemented during our study period and thus a full cycle of retirees has not had a chance to attend one of the programs.
} 
The objectives of Survey One were to determine employee understanding levels regarding their employer's pension and health benefits, their knowledge of national retirement plans such as Social Security and Medicare, their financial literacy, and their current retirement plans. To assess the current level of knowledge regarding national retirement plans, the survey asked about Social Security early and normal retirement ages as well as early retirement penalties, cost of living increases, and the age of eligibility for Medicare. In addition, participants were asked benefit and eligibility questions concerning their employer defined benefit plans and their own 401(k) or 403(b) accounts.

This survey also included several questions related to basic financial literacy. Survey One also asked participants the age that they expected to retire, when they expected to start Social Security benefits, what the expected level of benefits would be, and what benefits they expected to receive from their employer-provided retirement plans. Questions probed employee intentions concerning annuitization of pension assets and work plans after they retired from their current employer. Finally, Survey One contained a series of economic and demographic questions concerning current income, wealth, age, marital status, and the work, income, and retirement benefits of any spouse or partner.

The primary objectives of Survey Two were to determine how participants evaluated the seminar, whether they enhanced their knowledge of retirement programs, and whether the new information changed their retirement plans. To assess the employees' impression of the seminars, the first section of Survey Two asked respondents if the program provided useful information, if the information was presented at the right level for them, if the presenters were of high caliber, if they felt better able to make retirement decisions after completing the program, and whether they valued the program as an employee benefit. The next two sections of Survey Two repeated many 
Survey One questions concerning retirement intentions and knowledge. By comparing the answers given across both surveys, we assess the change in the respondent's knowledge about retirement programs, financial literacy, and whether participants changed their retirement plans.

Means of various demographic, economic, and retirement plans characteristics are shown in Table 2. The sample is composed of 840 workers age 50-65 with a mean age of 57.8 years. Males represented 54 percent of the employees, while 76 percent of respondents are married, and they have an average of 25 years of service with their current employer. In general, these are relatively high earners with above-average wealth.

\section{[Table 2]}

\section{Did Participant Financial Literacy Rise?}

The primary objectives of our research were to answer two key questions concerning workplace financial education programs. First, do employer-provided retirement planning programs increase financial literacy and knowledge about company and national retirement programs? Second, if financial literacy is increased, how does this enhanced knowledge affect workers' retirement plans? To examine the impact of financial education programs, we use the PARS data described above, which includes merged survey responses from the five employers.

To examine the level of financial literacy and knowledge of retirement programs prior to the seminar, the participants were asked a series of financial literacy and retirement program questions. The following analysis is based on 10 of these questions. The questions, along with a summary of correct answers and percent answering correctly are reported in Table 3. As reported in the bottom row of Table 3 , the average number of correct responses prior to the seminar is 6.2 ; afterwards the average number of correct answers rose to 7.5 , indicating a substantial level of learning among program participants. In general, the questions on which the 
lowest percentage of respondents gave the correct answers (P2 to P5) are those questions that relate to Social Security eligibility ages and how Social Security benefits vary with age and over time. $^{7}$

\section{[Table 3]}

The average knowledge score after the seminar for the entire sample is significantly higher than the average score prior to the seminar. Figure 1 shows the distribution of participants' knowledge scores (the number of correct answers) before and after the seminar. Prior to the seminar, 39 participants score a perfect 10 while 431 participants have scores of six or lower. After the seminar, 125 participants have correct answers for all 10 questions and only 204 have a score of six or fewer. ${ }^{8}$

\section{[Figure 1]}

Figure 2 shows the change in knowledge achieved during the seminar. Overall, 565 participants (67 percent of the sample) improved their knowledge scores. The knowledge score is unaffected for 174 individuals ( 21 percent of the sample), while 101 respondents (12 percent of

${ }^{7}$ It should not be surprising that many older workers do not know the basic eligibility and plan characteristics of national retirement programs. Key parameters of Social Security, Medicare, and pension regulations are based on legislation passed at different points in time and have different objectives. As a result, many alternative ages are specified in these programs that determine access to retirement income. A recent study (US GAO 2007) summarized these many different retirement age-related rules ranging from age 55, the age of eligibility for drawing certain pensions without penalties if leaving an employer, to age $70 \frac{1}{2}$ which is the age for mandatory withdrawals from pension plans to avoid tax penalties. While confusion over these ages is understandable, the retirement income of workers depends on their knowledge of these ages and the timing of their retirement decisions.

${ }^{8}$ Some critical variables in the index changed between Survey One and Survey Two. In results not shown, 31 percent of the responses in Survey One on the age at which one can begin receiving normal Social Security benefits were too low and 20 percent were too high. Both of these percentages dropped considerably in Survey Two; 20 percent were too low and 10 percent were too high. 
the sample) show a slight decrease in their financial knowledge. Panel B illustrates the knowledge gain sorted by the base level of financial knowledge from Survey One. Most importantly, those with initial low scores achieve substantial increases in their knowledge of retirement plans. Of the 431 individuals with low pre-seminar knowledge scores $(6$ or fewer correct answers), 357 (83 percent) improve their knowledge scores with 40 percent achieving increases of 3 or more additional correct answers. For this reason, we conclude that the preretirement planning seminars did increase financial literacy for almost all participants, with large gains among those with relatively little knowledge prior to the event.

\section{[Figure 2]}

It should be emphasized that the gains in knowledge are observed across all economic and demographic characteristics of the participants. Table 4 shows the knowledge index by subsets of the sample based on various employee characteristics. There is a 1.3 point gain on a 10 point scale in the mean score of the entire population. Younger participants, those aged 50-61, have a greater increase in their knowledge scores than the older participants, a gain so large that it eliminates the age difference in knowledge observed prior to the program. Knowledge gains also are slightly larger for those with 20 or fewer years of service than those with more than 20 years of service. Women have larger gains in knowledge than men but still have a lower knowledge score than men after the program.

\section{[Table 4]}

Interestingly, people with lower self-assessed knowledge scores prior to the seminar have a much larger gain in mean scores than those with a higher initial self-assessed level of knowledge (1.50 compared to 1.06). This is another indication that the programs are beneficial to those with relatively little knowledge of their retirement plans. There also is evidence that those 
with some college learn more from the seminars than those with no more than a high school education. Workers with some college start with a higher initial level of knowledge than those who have less education (6.44 to 5.01) and the gap widens even further (7.81 to 6.16) after the workshops. This implies that education and retirement planning programs have complementary effects on learning. Overall, these data provide important statistical support for the conclusion that workplace education is effective in increasing financial literacy for older workers and the gains are often greater for those that enter the event with the lowest levels of financial literacy.

Table 4 also shows how knowledge scores changed in each of the five companies. Employer E had the largest increase in knowledge scores (1.75 points). This employer introduced the seminars during our study period and invited all employees age 50 and older to attend. Scores increased by 1.35 points or more at employers A, B, and D. The score increase was lowest at Employer C ( 0.59 points), but that may be partly attributable to a relatively high score in Survey One.

\section{Did Greater Knowledge Change Retirement Plans?}

After participating in the workplace educational event and increasing their financial literacy, how do workers respond? Does enhanced knowledge result in changes to planned retirement behavior and the management of retirement wealth? Table 5 compares responses between Survey One and Survey Two for four key variables: planned retirement age, planned age to begin receiving Social Security benefits, plans for working after retirement, and the decision to annuitize. Although mean planned retirement age increases only slightly due to movements in both directions, 31.1 percent of seminar participants changed planned retirement age (as measured by their expected age of retirement on Survey Two in comparison to their expected age of retirement as indicated on Survey One). Figure 3 demonstrates graphically how 
planned retirement age changed between Survey One and Survey Two. There is a tendency toward later planned retirement after Survey Two among those who initially had planned to retire before age $65 .^{9}$

\section{[Table 5]}

\section{[Figure 3]}

Mean planned Social Security claiming age was also influenced; 36.7 percent of respondents indicated a change in the age they plan to start receiving Social Security benefits, of which 67.6 percent indicate plans to postpone benefit receipt. ${ }^{10}$ This variation is reasonable as individuals are constrained in the front end (i.e., it is not possible to claim Social Security earlier than at age 62) while one can theoretically postpone retirement indefinitely. ${ }^{11}$ Figure 4

${ }^{9}$ Appendix Table A-2 details the change in planned retirement age between Survey One and Survey Two. Among those who initially planned to retire at age 62 to 64 in Survey One, 21 percent reported a later planned retirement date in Survey Two whereas only 8 percent report an earlier date. Among those who planned to retire at age 65 in Survey One, we find that 14 percent plan to retire earlier and 25 percent plan to retire later after Survey Two. At an initial planned retirement age 66 and higher there is slightly more movement toward an earlier retirement (14 percent) than there is movement toward later retirement (11 percent).

${ }^{10}$ Of the 89 individuals that report in Survey Two an earlier planned claiming age than stated in Survey One, the average decline 2.34 years, with the largest change being a drop of 6 years. Of the 186 individuals which reported plans to postpone claiming Social Security, the largest change was by 11 years, with a mean of 2.31 years.

${ }^{11}$ There is some tendency for retirement and Social Security claiming decisions to be made in tandem as presented in Appendix Table A-3. Among the 163 employees who decided to delay retirement, 53 percent also said that they planned to delay Social Security claiming. Most of the remaining respondents reported no change in planned Social Security claiming, and nine percent reported earlier planned Social Security claiming ages. Among the 66 respondents who said they planned to retire earlier, 36 percent said they would claim Social Security earlier and 18 percent said they would delay Social Security claiming. 
graphically depicts how the age at which the individual plans to begin drawing on Social Security changed between Survey One and Survey Two. There was over an 10 percentage point increase in the number of attendees indicating plans to work after retirement, while the number indicating uncertainty regarding plans to work after retirement dropped by 10 percentage point. These changes in age at which to draw on retirement benefits and plans to work after retirement may be due to a better understanding of retirement income needs and total expected retirement wealth.

\section{[Figure 4]}

Table 5 highlights other changes which include a shift in plans regarding pension and supplemental retirement saving account distributions. Prior to the seminar, there was considerable uncertainty regarding whether to annuitize account balances in supplemental retirement plans and whether to take lump sum distributions from the defined benefit plans. Post seminar, fewer respondents indicate uncertainty regarding these important decisions. Before the seminar, approximately 19 percent of the sample planned to annuitize some or all of their supplement plan funds. This increased to 26 percent after the seminar, with the proportion that had not decided declining by 10 percentage points. However, almost half of the participants were still undecided in regards to annuitization. Pre-seminar, approximately 27 percent of the employees were certain that they want to take a lump sum distribution of their defined pension benefit while 62 percent were uncertain. Responses to this set of questions post-seminar indicate little change. These results suggest that deciding whether to take a lump sum distribution from one's pension or to annuitize one's $401(\mathrm{k})$ balance are complicated decisions that require substantial consideration. 
Are these changes in retirement plans associated with improved financial knowledge and better understanding of pension plan parameters? To address this question, we use the following framework. Before attending the retirement planning seminar, each worker has a planned retirement age based on a host of factors including expected longevity, wealth, expected future earnings potential, features of public and private pensions, and spousal retirement plans. During the seminar, the employee obtains information from the various presentations, has a chance to ask questions, and discusses retirement issues informally with other attendees. In response to this expanded set of information, the worker will either confirm his or her original choice of retirement age or make an adjustment toward earlier or delayed retirement.

Formally, we model this thought process with a linear equation where the planned retirement age $(R)$ is a function of knowledge (Info) at a given point in time and personal characteristics $(X)$ related to retirement decision making (e.g., age, gender, earnings and marital status will be reasonable proxy variables for longevity, future earnings, wealth and household decision making). Before the seminar $(\mathrm{t}=1)$, we write that the planned retirement age in period $1, R_{l}$, is a linear function of demographic characteristics, $X$, and the information set, Info.

$$
R_{i 1}=\alpha_{1}+\beta_{1} X_{i 1}+\gamma_{1} \text { Info }_{i 1}+\epsilon_{i 1}
$$

The planned retirement age after the seminar, $R_{2}$, is the planned retirement age in period 1 plus any revision to the retirement plan that is made as a function of demographic characteristics, $X$, and the change in knowledge.

$$
R_{i 2}=R_{i 1}+\alpha_{2}+\beta_{2} X_{i 2}+\gamma_{2}\left(\text { Info }_{i 2}-\operatorname{Info}_{i 1}\right)+\epsilon_{i 2}
$$

In the short time between Survey One and Survey Two, we assume that $X_{i 2}=X_{i 1}=X_{i}$. Rearranging equation (2), we find that the change in planned retirement age is a function of demographic 
characteristics and the change in the information set. Equation (3) is our main regression equation:

$$
\Delta R_{i}=R_{i 2}-R_{i 1}=\alpha_{2}+\beta_{2} X_{i}+\gamma_{2}\left(\operatorname{Info} o_{i 2}-\operatorname{Info} o_{i 1}\right)+\epsilon_{i 2}
$$

The change in planned retirement age, $R$, will depend on: (a) how people with given values of $X$ reevaluate their retirement decisions $\left(\alpha_{2}\right.$ and $\left.\beta_{2}\right)$; (b) the effect of changes in the information set, $\left(\gamma_{2} \Delta\right.$ Info $)$; and (3) random noise that we cannot capture in our model or data $\left(\varepsilon_{2}\right)$.

In practice, workers have a probability density function for expected retirement age instead of a 100 percent probability at a single age. We assume that workers report the age that has the highest $\mathrm{p}$-value of occurring. Changes in the probability density function would still be a function of $X$ and changes in Info. Empirically we estimated three closely related probit models: the probability that $R_{2}$ does not equal $R_{1}$, the probability that $R_{2}>R_{1}$, and the probability that $R_{1}>R_{2}$

To estimate the impact of the learning that took place at the seminar on planned retirement age, this study focuses on the participant knowledge scores in the PARS data. We start with an aggregate index of knowledge based on the 10 items in Table 3; this variable is scaled to be between zero and ten. Because our focus is on planned retirement age, we also break down this index into its four major components: (1) knowledge about Social Security and Medicare eligibility, (2) general knowledge of public programs, (3) overall financial knowledge, and (3) company-specific knowledge. Finally, we examine the role of each individual variable in the knowledge score index as an independent variable. In effect this means that each knowledge variable can have its own coefficient, whereas the aggregate index constrains the coefficients of all 10 variables to be the same. 
Table 5 and Figure 3 suggest that information received during the pre-retirement seminar did have an effect on the participant's planned retirement age. In Table 6, we explore the effect of this increase in financial literacy on planned retirement age by estimating the probability of a change in planned retirement age based on the three different measures of learning. Panel A explores the effects of an increase of financial literacy using an aggregate measure of the change in financial knowledge (based on responses to knowledge questions before and after the seminar) while controlling for demographics, wealth, and the individual's employer. The change in knowledge score variable indicates the change in the total number of correct responses for the 10 knowledge score questions. Column (1) presents the average marginal effects from a probit regression on the probability of a change expected retirement age. Results indicate that an increase in the aggregate knowledge score is associated with an increase in the probability of a change in expected retirement age.

\section{[Table 6]}

Columns (2) and (3) further define the change by presenting the average marginal effects of a regression on the probability of a delay in expected retirement and the probability of an earlier expected retirement, respectively. In Column (2), the change in the knowledge score variable is positive and statistically significant which indicates that a change in knowledge score is associated with increased probability of delaying retirement. In Column (3), the change in knowledge score is small and statistically insignificant, indicating that a change in the aggregate knowledge score did not lead to an increase in the probability of an earlier planned retirement.

Table 6, Panel B presents a similar analysis, but disaggregates the change in knowledge score to four distinct groups to better understand which areas of learning impact retirement plans. Results presented in Table 6, Column (1) indicate that both learning about public program 
eligibility and company-specific retirement plans lead to an increase in the probability of a change in planned retirement age. Knowledge about the age at which an individual is eligible to receive Social Security may have a significant impact on retirement plans if one's prior understanding of the eligibility for these programs was incorrect. Accordingly, a better understanding of company specific retirement guidelines including pension plan distributions and retiree health benefits may also influence retirement plans.

In Table 6, Column (2), Panel B, we see that learning about public program eligibility is associated with an increase in the probability of a delay in planned retirement. In the specification presented in Table 6, Column (3), we see that learning about investment diversification and inflation is associated with decrease in the probability of earlier retirement. A better understanding of inflation could influence the employee's perception of retirement wealth which might make it less likely he would move up his planned retirement age.

Table 6, Panel $\mathrm{C}$ further disaggregates the change in knowledge score by presenting the change in response to each of the 10 questions. By doing so, we can determine how learning about each individual item influenced retirement plans. In Column (1), we see that the effect of leaning about public program eligibility is driven by learning about the age at which the individual can receive full Social Security benefits and the age at which an individual will be eligible for Medicare. As Social Security provides a significant source of retirement income for the individual and health insurance is costly, a better understanding of eligibility for these two important programs is likely to influence retirement plans. ${ }^{12}$ The results in Column (1) also show that learning about employer pension eligibility is positively associated with a greater

${ }^{12}$ Supporting the claim that Medicare eligibility influences planned retirement behavior, Kopczuk and Song (2008) use administrative files from the Master Beneficiary File to show that there are a relatively large number of individuals who claim retirement benefits around their $65^{\text {th }}$ birthday. 
probability of a change in planned retirement age. The Social Security eligibility coefficients for the delayed retirement probit in Column (2) are similar to those in Column (1). They have the same sign as in Column (1), but are of smaller magnitude. The similarity between the results presented in these two columns is due to the fact that of those that do change expected retirement age, they tend to do so by delaying retirement.

In Column (3), Table 6, Panel C, we see that two of the three questions included in the "Public Program - General" index are independently statistically significant at the ten percent level but of opposite sign. Learning that the reduction in Social Security benefits due to claiming early retirement is permanent is, paradoxically, associated with an increase in the probability of earlier retirement. Learning that Social Security benefits are increased by the rate of inflation is associated with a decrease in the probability of earlier retirement. For those who thought that benefits increased more rapidly than inflation, this information would have a negative impact on the individual's perceived retirement wealth which could entice him to consider an earlier date of retirement than currently planned. This is somewhat consistent with the results for the financial knowledge question on inflation and retirement income. Those who learned how inflation can erode real income were less likely to change their planned retirement age to be earlier. The relationship between knowledge and retirement plans is complex and depends on the direction of knowledge errors. By disaggregating the knowledge score index and exploring each component individually, we see how each piece of knowledge influences the individual's planned retirement age.

Another key decision facing individuals is when to take up Social Security benefits. Although the life-cycle framework can be used to model retirement decision making, some behaviors are inconsistent with this approach. One such example is the spike in Social Security 
claiming which occurs at the full retirement age (NRA). Behaghel and Blau (2012) explore the reasons for the spike in benefits claiming that occurs at age 65 by examining the increase in the full retirement age. ${ }^{13}$ They note that the spike may be due to an endorsement effect. As full retirement age had been 65 since the program began and has only recently been changed, ${ }^{14}$ individuals may interpret this age as the "recommended" retirement age. It may also be that individuals are loss adverse and are unwilling to move away from the full retirement age.

Both of these behavioral explanations for the spike at age 65 highlight the potential impact of learning on planned Social Security claiming behavior. Table 7 replicates the models of Table 6 for a different retirement decision - the age at which one begins receiving Social Security benefits. In Table 7, Panel A, we see that changes in the aggregate knowledge score are associated with higher probability of changing one's Social Security claiming age, higher probability of delaying that age and higher probability of an earlier claiming age. When the aggregate index is broken down into four major components, it is clear that Social Security knowledge is driving the Panel A results. Table 7, Panel C confirms the role of two key Social Security parameters: the age at which one is eligible for full or unreduced Social Security benefits and the Medicare eligibility age. Improved knowledge for the "normal retirement age" for Social Security is associated with greater probability of changing the Social Security claiming. ${ }^{15}$ Improved knowledge in Medicare eligibility is associated with greater probability of

\footnotetext{
${ }^{13}$ In 1983, Social Security reform increased the full retirement age from 65 to 66 , in two month increments, for cohorts born from 1943-1954.

${ }^{14}$ The first cohort to experience the increase in full retirement age resulting for the 1983 Social Security were those reaching their full retirement age in 2004-2009.

${ }^{15}$ This is consistent with findings by Song and Manchester (2007) showing that changes in the full retirement age resulted in a shift of the spike to the new full retirement age among affected cohorts.
} 
changing Social Security claiming age and greater probability of planning to claim Social Security at an earlier age.

\section{[Table 7]}

Looking across Tables 6 and 7, misperceptions about the ages of eligibility for normal Social Security and Medicare are strongly related to changes in retirement plans. Appendix Table A-4 details the planned retirement and Social Security claiming ages associated with learning about normal Social Security eligibility. There were 113 people in the sample who underestimated the eligibility age for normal Social Security in Survey One but correctly reported the age in Survey Two. Within this group, 12 percent changed their planned retirement age, 27 percent changed their planned Social Security claiming age and 26 percent changed both. Of the 83 who overestimated this eligibility age in Survey One, 8 percent changed their planned retirement age, 28 percent changed their planned Social Security claiming age, and 30 percent changed both. In other words, over half of those who corrected misperceptions about normal Social Security eligibility changed their retirement plans.

The means presented in Table 5 indicated that plans for working after retirement and plans for annuitizing pension wealth also shifted in response to the seminar. However, for both of these categories the major shift was in a reduction of those reporting "have not yet decided." In fact, for the choice of whether to annuitize one's pension, in Survey Two the modal response is "have not yet decided." We did examine how changes in financial literacy and pension knowledge affected plans to work after retirement. In results not reported (available upon request), we find again that changes in knowledge are related to changes in retirement plans, but the patterns are somewhat mixed. While an increase in the aggregate knowledge score reduced 
the probability of planning not to work after retirement by a very small 0.8 percentage points, when disaggregating there is no consistent pattern.

\section{Conclusions}

Many older workers have a rather low level of financial literacy and understanding of their retirement programs. Limited or inaccurate information may lead them to make poor retirement decisions, undermining their ability to achieve retirement income adequacy. We show how pre-retirement planning programs offered by five large employers improved financial and pension literacy and how this changed employees' reported retirement plans.

Employers who offer pre-retirement planning seminars as an employee benefit are naturally seeking to ensure that these programs are effective and valued by employees. The feedback we received in Survey Two, conducted immediately after attending a seminar, indicated participants had a very positive experience and believed that the seminars are helpful. Some 95 percent of respondents state that the programs provided all or most of the information needed for them to make important retirement decisions. Eighty-six percent of respondents rate the programs very good or excellent, and 93 percent find the presenters and program leaders to be very good or excellent. Eighty-seven percent of respondents report believing that they will be able to make better retirement choices after participating in the seminar. Importantly, for companies considering whether to provide such programs to their employees, 72 percent of individuals report that the programs raised their awareness of the benefits provided by their employers. Accordingly, participants give high marks to the quality of the programs, believing that the programs provide the information they needed, and give their employers credit for offering these programs. 
The seminars also may be creating value for employers by reducing the transaction costs of managing pension plans. Many employees will have the same questions which can be answered more efficiently in a seminar environment than in one-on-one meetings with human resource staff. Consequently, employers can facilitate the transition into retirement by providing the means for workers to increase their understanding of key retirement concepts. The results of this study should provide encouragement to employers considering whether to adopt preretirement planning programs. Based on our assessment of these initial data, employer provided financial education programs can increase employee knowledge of retirement programs and assist them in making better retirement choices. This enables their employees to achieve a more desirable retirement. Also, to the extent that the firm has designed its pension plan to optimize employee retention and the age structure of its workforce, the seminars enhance the probability that these corporate goals will be achieved.

\section{REFERENCES}

Bayer, Patrick J., B. Douglas Bernheim, and John Karl Scholz. 2009. "The Effects of Financial Education in the Workplace: Evidence from a Survey of Employers." Economic Inquiry 47(4): 605-624.

Behaghel, Luc, and David M. Blau. 2012. "Framing Social Security Reform: Behavioral Responses to Changes in the Full Retirement Age."American Economic Journal: Economic Policy 4(4): 41-67.

Benitez-Silva, Hugo, and Debra S. Dwyer. 2005. "The Rationality of Retirement Expectations and the Role of New Information." The Review of Economics and Statistics 87(3): 587592.

Bernheim, Douglas. 1995. "Do households appreciate their financial vulnerabilities? An analysis of actions, perceptions, and public policy," in Tax Policy and Economic Growth, American Council for Capital Formation, Washington, DC, pp. 1-30. 
Bernheim, Douglas. 1998. "Financial illiteracy, education and retirement saving," in Olivia Mitchell and Sylvester Schieber (eds.), Living with Defined Contribution Pensions, University of Pennsylvania press, Philadelphia, pp. 38-68.

Bernheim, B. Douglas, and Daniel M. Garrett. 2003. "The Effects of Financial Education in the Workplace: Evidence from a Survey of Households." Journal of Public Economics 87(78): $1487-1519$.

Chan, Sewin, and Ann Huff Stevens. 2008. "What You Don't Know Can't Help You: Pension Knowledge and Retirement Decision-Making." The Review of Economics and Statistics 90(2): 253-266.

Clark, Robert and Madeleine d'Ambrosio. 2003. "Ignorance is Not Bliss," TIAA-CREF Research Dialogue.

Clark, Robert L., Madeleine B. d'Ambrosio, Ann A. McDermed, and Kshama Sawant. 2006. "Retirement Plans and Saving Decisions: The Role of Information and Education." Journal of Pension Economics and Finance 5(1): 45-67.

Clark, Robert, Melinda Morrill, and Steven Allen. 2011. Evaluating Employer-Provided Financial Education Programs for Pre-Retirees, Report prepared for the FINRA Investor Education Foundation. Available online at: http://www.finrafoundation.org/web/groups/foundation/@foundation/documents/foundati on/p124011.pdf

Clark, Robert L., Melinda Sandler Morrill, and Steven G. Allen. 2012a. "Effectiveness of Employer-Provided Financial Information: Hiring to Retiring." American Economic Review 102(3): 314-318.

Clark, Robert L., Melinda Sandler Morrill, and Steven G. Allen. 2012b. "The Role of Financial Literacy in Determining Retirement Plans," Economic Inquiry, 50(4): 851-866.

Goda, Gopi Shah, John B. Shoven, Sita Nataraj Slavov. 2012. "Does Stock Market Performance Influence Retirement Intentions?” Journal of Human Resources, 47(4): 1055-1081. 
Gustman, Alan L., Thomas L. Steinmeier, and Nahid Tabatabai. 2012. "Financial Knowledge and Financial Literacy at the Household Level." American Economic Review 102(3): 309-313.

Hastings, Justine S., Brigitte C. Madrian, and William L. Skimmyhorn. 2012. "Financial Literacy, Financial Education and Economic Outcomes." National Bureau of Economic Research Working Paper No. 18412.

Hilgert, Marianne and Jeanne Hogarth. 2002. "Financial Knowledge, Experience and Learning Preferences: Preliminary Results from a New Survey on Financial Literacy," Consumer Interest Annual 48.

Kopczuk, Wojciech, and Jae Song. 2008. "Stylized Facts and Incentive Effects Related to Claiming of Retirement Benefits Based on Social Security Administration Data." Michigan Retirement Research Center Working Paper 2008-200

Liebman, Jeffrey B., and Erzo F. P. Luttmer. 2011. "Would People Behave Differently If They Better Understood Social Security? Evidence From a Field Experiment.” National Bureau of Economic Research Working Paper No. 17287, August 2011.

Lusardi, Annamaria. 2005. "Saving and the Effectiveness of Financial Education." Journal of Financial Transformation, 15: 159-169.

Lusardi, Annamaria.(ed.). 2008. Overcoming the Saving Slump: How to Increase the Effectiveness of Financial Education and Saving Programs. Chicago: University of Chicago Press.

Lusardi, Annamaria, and Olivia S. Mitchell. 2006. "Financial Literacy and Planning: Implications for Retirement Wellbeing." Pension Research Council Working Paper n. 1.

Lusardi, Annamaria, and Olivia S. Mitchell. 2007. "Baby Boomer Retirement Security: The Roles of Planning, Financial Literacy, and Housing Wealth." Journal of Monetary Economics 54(1): 205-224.

Lusardi, Annamaria, and Olivia S. Mitchell. 2011. "Financial Literacy and Planning: Implications for Retirement Wellbeing." National Bureau of Economic Research Working Paper No. 17078, May 2011 
Sabelhaus, John, Michael Brogdan, and Sarah Holden. 2008. Defined Contribution Plan Distribution Choices at Retirement: A Survey of Employees Retiring Between 2002 and 2007. Washington, DC: Investment Company Institute. http://www.ici.org/pdf/rpt 08 dedd.pdf

Song, Jae, and Joyce Manchester. 2007. "Have People Delayed Claiming Retirement Benefits? Responses to Changes in Social Security Rules." Social Security Bulletin 67(2): 1-23.

United States Government Accountability Office (USGAO). 2007. Federal Policies Offer Mixed Signals on When to Retire, Washington, DC: USGAO.

van Rooij, Maarten C. J., Annamaria Lusardi, and Rob J. M. Alessie. 2012. "Financial Literacy, Retirement Planning and Household Wealth.” Economic Journal 122(560): 449-478

Wray, David. 2008. Testimony Before the ERISA Advisory Council Working Group on Spend Down of Defined Contribution Plan Assets at Retirement. Chicago, IL: Profit Sharing/401k Council of America, July 16. Available online at: http://www.psca.org/Portals/0/pdf/July\%2016\%202008\%20 testimony.pdf 
Figure 1. Knowledge Score Pre and Post- Seminar

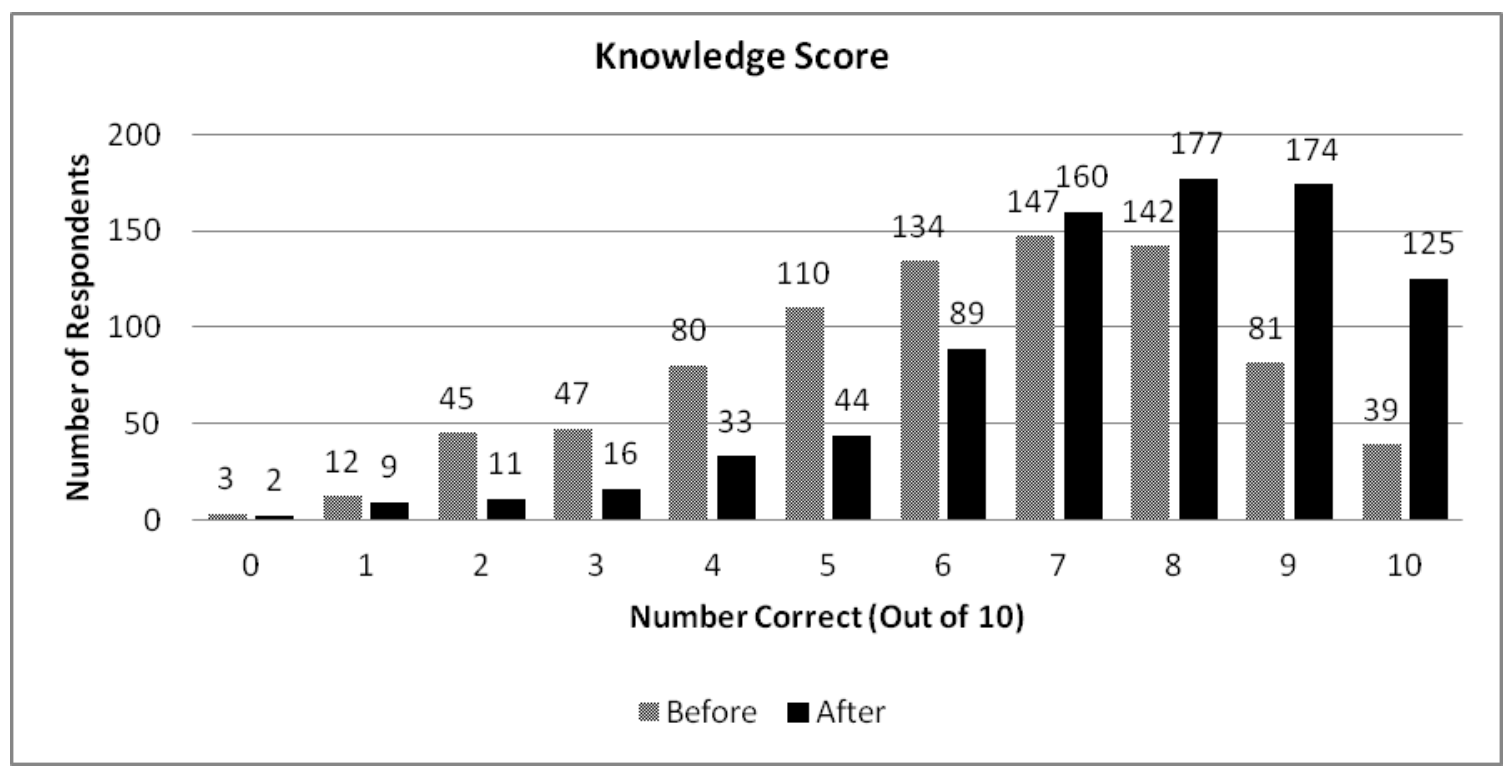

Notes: Aggregate knowledge scores for respondents in the PARS data who answered at least five out of ten questions in both Survey One (before the seminar) and Survey Two (after the seminar). Missing or blank responses are treated as incorrect. 
Figure 2. Changes in Knowledge Scores Pre-Post Seminar

Panel A. All Participants

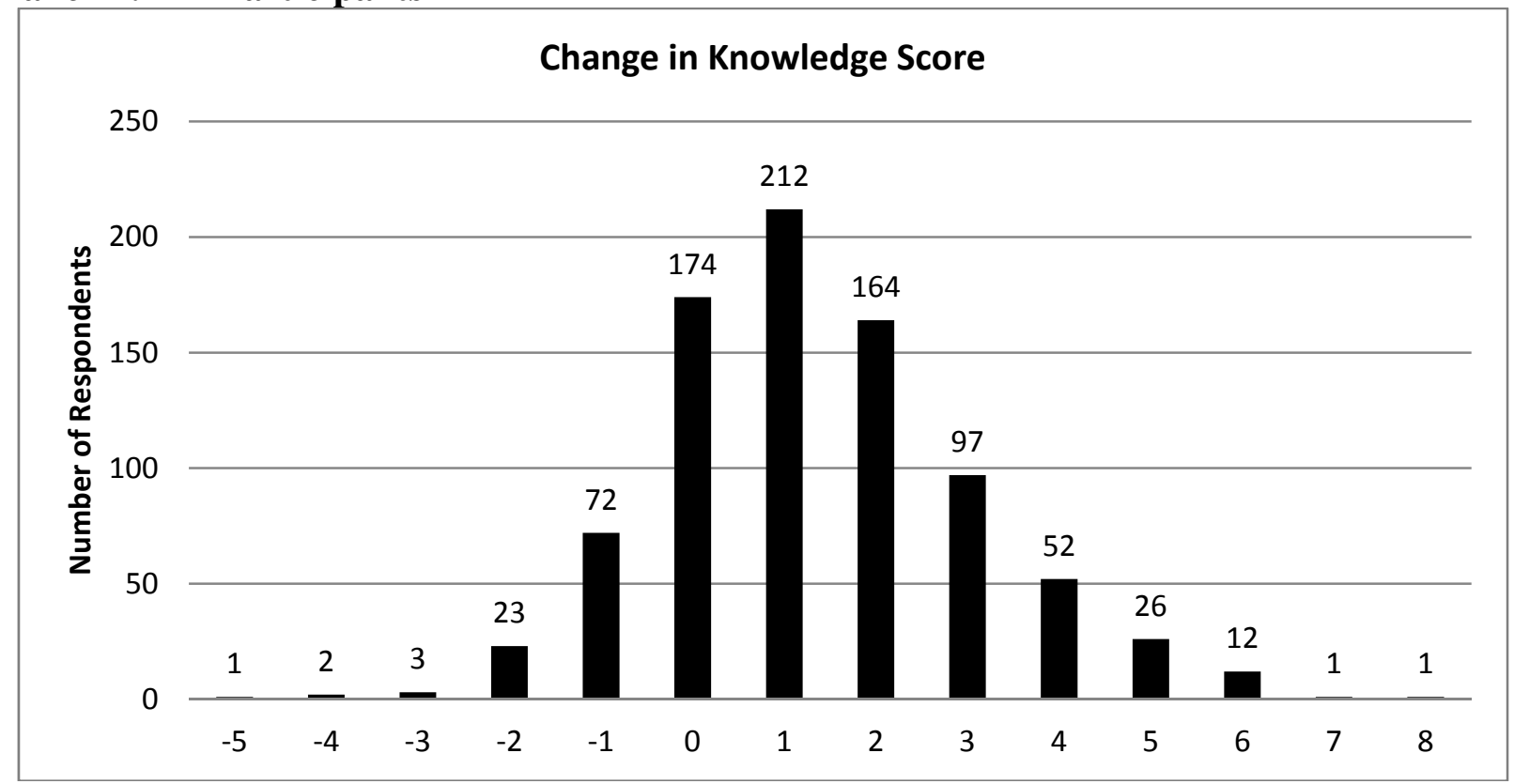

Panel B. Separately by High and Low Pre-Seminar Knowledge

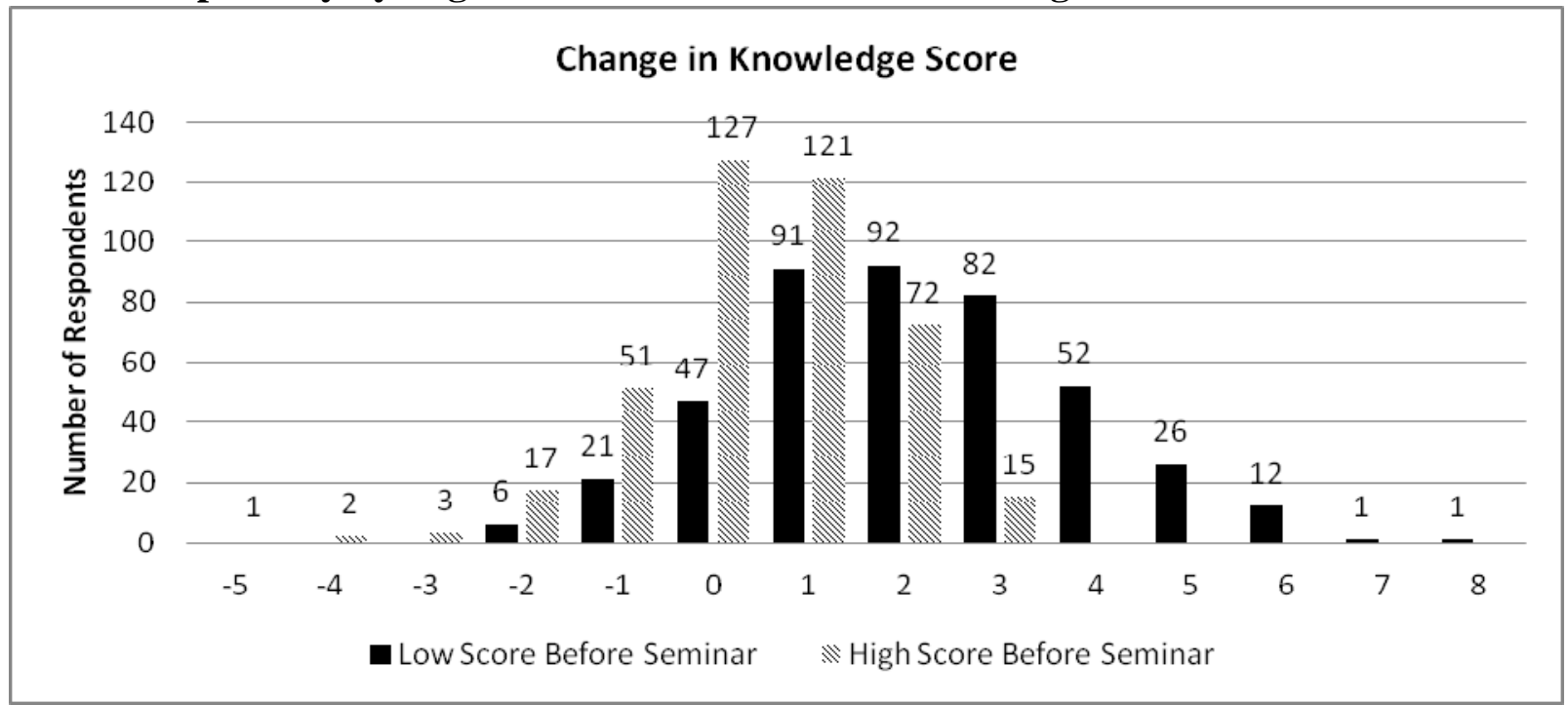

Notes: Aggregate knowledge scores for respondents in the PARS data who answered at least five out of ten questions in Survey One (before the seminar) and Survey Two (after the seminar). Missing or blank responses are treated as incorrect. Low scores were 6 or below, high scores were 7 or more questions answered correctly. 
Figure 3: Expected Retirement Age by Survey, Weighted Scatterplot

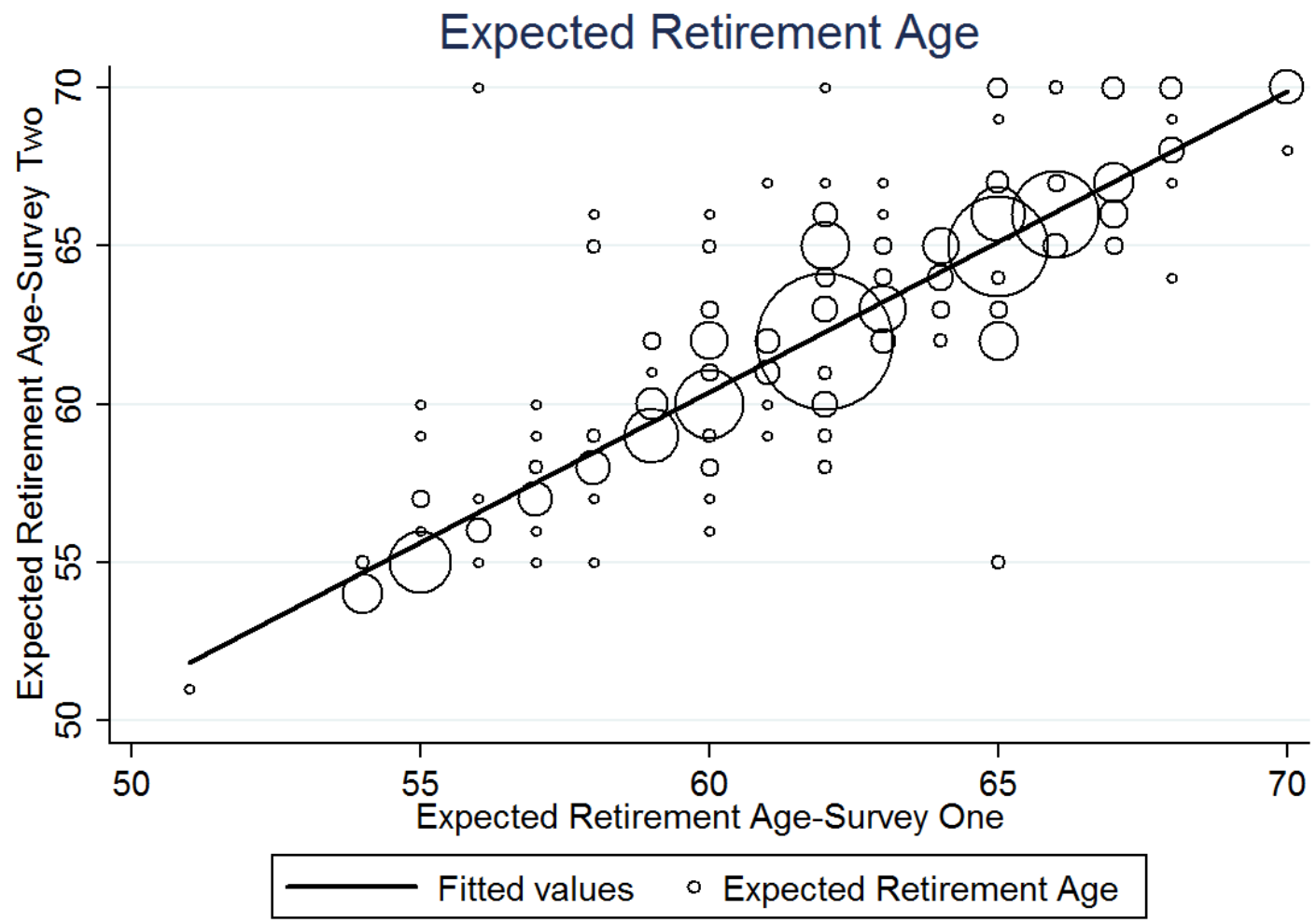

Notes: The sample consists of the 840 respondents from the PARS dataset. The size of the plot point indicates the number of respondents indicating the Survey One and Survey Two expected retirement age combination. 
Figure 4: Expected Social Security Claiming Age by Survey, Weighted Scatterplot Expected Social Security Claiming Age

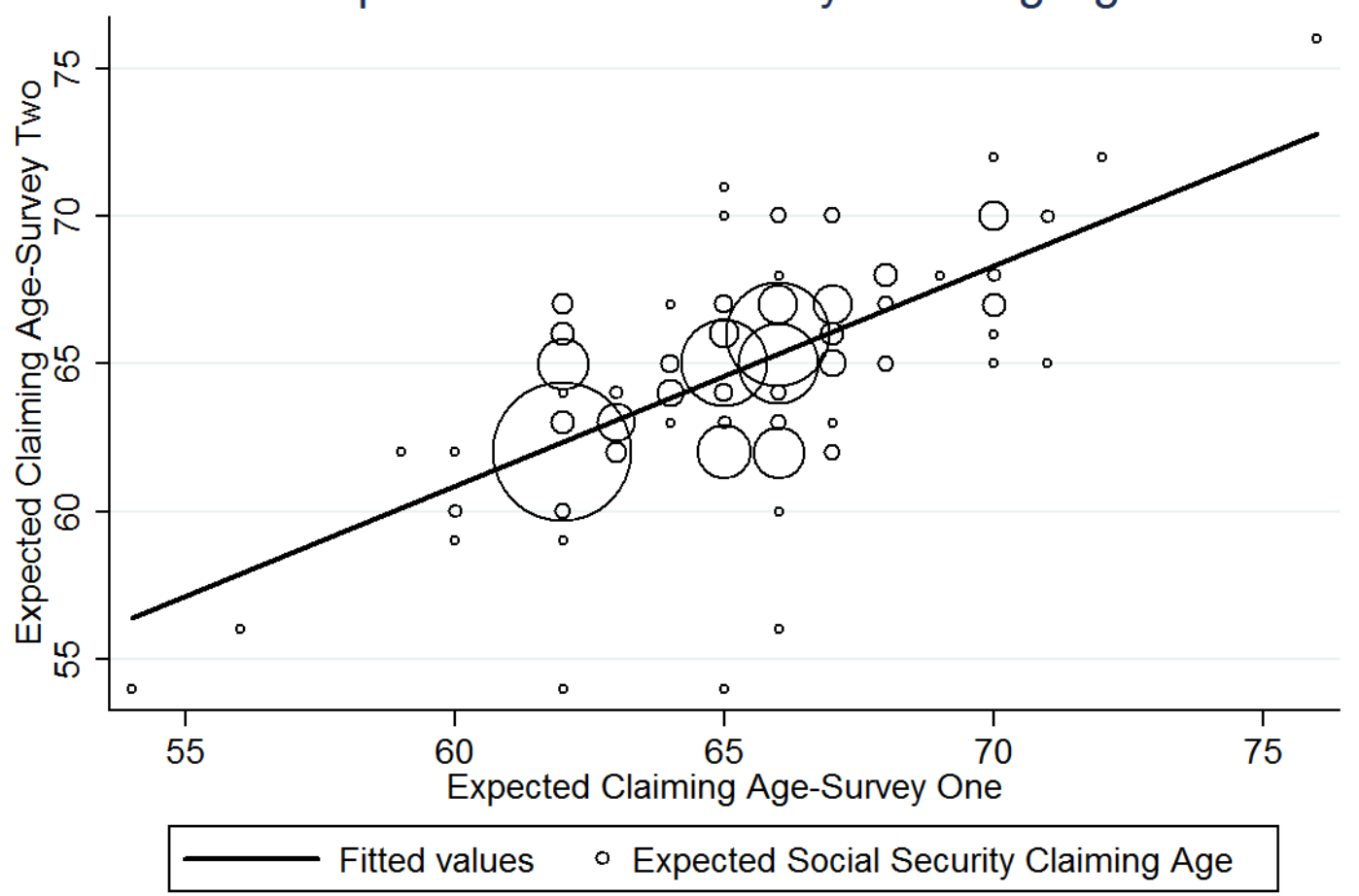

Notes: The sample is the PARS dataset further limited to those observations with valid Social Security age responses in both Survey One and Survey Two $(\mathrm{N}=728)$. The size of the plot point indicates the number of respondents indicating the Survey One and Survey Two expected retirement age combination. 
Table 1. Description of Employers and Seminars

\begin{tabular}{|c|c|c|c|c|c|c|c|c|}
\hline $\begin{array}{l}\text { Employer } \\
\text { (survey method) }\end{array}$ & Industry & $\begin{array}{l}\text { Requirements to } \\
\text { attend }\end{array}$ & $\begin{array}{l}\text { Seminar } \\
\text { length }\end{array}$ & $\begin{array}{l}\text { Seminar } \\
\text { description }\end{array}$ & $\begin{array}{l}\text { Number of } \\
\text { Seminars }\end{array}$ & $\begin{array}{l}\text { Number } \\
\text { attending } \\
\text { a seminar }\end{array}$ & $\begin{array}{l}\text { Total } \\
\text { survey } \\
\text { responses }\end{array}$ & $\begin{array}{l}\text { Final } \\
\text { PARS } \\
\text { sample }\end{array}$ \\
\hline $\begin{array}{l}\text { Employer A } \\
\text { (hard copy) }\end{array}$ & $\begin{array}{l}\text { Medical } \\
\text { technology }\end{array}$ & Retirement-eligible & $1 / 2$ day & Run by Ayco & 31 & $500 *$ & 472 & 351 \\
\hline $\begin{array}{l}\text { Employer B } \\
\text { (electronic) }\end{array}$ & University & $\begin{array}{l}\text { Immediately prior } \\
\text { to retirement }\end{array}$ & Full day & In house & 4 & 130 & 71 & 64 \\
\hline $\begin{array}{l}\text { Employer C } \\
\text { (hard copy) }\end{array}$ & Energy & $\begin{array}{l}\text { Retirement- } \\
\text { eligible, only once } \\
\text { per } 5 \text { years }\end{array}$ & $\begin{array}{l}\text { 2008: Full day } \\
\text { 2009: } 1 / 2 \text { day }\end{array}$ & $\begin{array}{l}\text { 2008: In-house } \\
\text { with outside } \\
\text { speakers } \\
2009: \text { In-house } \\
\text { only }\end{array}$ & 27 & 333 & 295 & 156 \\
\hline $\begin{array}{l}\text { Employer D } \\
\text { (hard copy) }\end{array}$ & $\begin{array}{l}\text { Forest } \\
\text { products }\end{array}$ & Retirement-eligible & $21 / 2$ days & $\begin{array}{l}\text { In-house with } \\
\text { outside speakers }\end{array}$ & 12 & 281 & 165 & 105 \\
\hline $\begin{array}{l}\text { Employer E } \\
\text { (electronic) }\end{array}$ & Energy & $\begin{array}{l}\text { Any employee over } \\
\text { age } 50\end{array}$ & Full day & $\begin{array}{l}\text { In-house with } \\
\text { outside speakers }\end{array}$ & 7 & 314 & 179 & 162 \\
\hline Totals & & & & & 85 & $1,559 *$ & 1,182 & 840 \\
\hline
\end{tabular}

Notes: The survey response is calculated as those responding to both Survey One and Survey Two. The total response rate to the surveys was 75.8 percent. The PARS data is limited to those who were born between 1943 and 1959 and who had valid responses to at least five out of ten knowledge questions, gender, age, tenure, education, and planned retirement age.

*We were not able to obtain an exact count of seminar attendees for several of the Employer A seminars. The estimated number of attendees reported here is based on discussions with seminar leaders and from projecting the response rate for seminars where attendance was reported. 
Table 2. PARS Data Descriptive Statistics

Age

Male

Married

Years of Service

Mean or Percent

57.8

$54.1 \%$

$76.3 \%$

24.7

Some College

$82.4 \%$

Covered by a Pension Plan

$93.2 \%$

Own Home

Self-Assessed Knowledge (1-7)*

$92.9 \%$

4.1

Years from Planned Retirement (Before)

4.6

Years from Planned Retirement (After)

4.9

Wealth and Earnings Variables:

Earnings -- Medium $(\$ 50 \mathrm{~K}-\$ 100 \mathrm{~K})$

$43.6 \%$

Earnings -- High $(\$ 100 \mathrm{~K}+)$

$31.4 \%$

401(k) Account Balance -- Medium (1-5 Years of

$61.9 \%$

Current Salary)

401(k) Account Balance -- High (More Than 5

$18.2 \%$

Years of Current Salary)

*Sample size for this question was less than 840 due to missing response.

Notes: Sample size is 840 respondents from the PARS dataset. All variables reported here are measured before the seminar. See Table 1 for a description of the dataset. 
Table 3. Participant Knowledge Before and After the Seminar

Financial Knowledge Questions

\begin{tabular}{c} 
Percent Answering \\
Correctly \\
Before After \\
Seminar Seminar \\
\hline
\end{tabular}

$84 \% \quad 91 \%$

F1 True or false? "Buying a single company stock usually provides a safer return than a diversified portfolio." False

F2 Assume that your retirement income increases by 2\% per year and that the annual rate of inflation is $4 \%$ per year. After one year, will you be able to:

a) buy more goods and services?

b) buy fewer goods and services?

$82 \% \quad 85 \%$

c) buy exactly the same amount of goods and services?

d) don't know

\section{Public Programs Questions}

P1 What is the earliest age that you can start Social Security benefits? 62

P2 What is the age that you can receive a full or unreduced Social Security benefit ("normal retirement age")? 66

P3 If you start Social Security benefits at the earliest possible age, you will receive a benefit that is _ percent of the benefit you would have received at the normal retirement age. $75 \%$

P4 Is the reduction in Social Security benefits for early retirement permanent or does the reduction end when you reach the normal retirement age?

Permanent

P5 After you start receiving Social Security benefits, these benefits are:

a) the same for the rest of my life

b) increased annually by the rate of inflation

c) increased annually but by less than the rate of inflation

d) increased annually but by more than the rate of inflation

e) Don't know

P6 What is the earliest age that you will be eligible for Medicare? 65

\section{Company-Specific Questions}

C1 Can you take a lump sum distribution of some or all of your pension plan (do not include income for your 401(k) account)?

Yes (all five companies)

C2 Does your company offer you the opportunity to stay in the company

health plan after you retire?

$37 \% \quad 53 \%$

$68 \% \quad 83 \%$

Yes (all five companies)

Average Knowledge Score (Out of 10)

$73 \% \quad 84 \%$

$68 \% \quad 88 \%$

Notes: Sample is 840 respondents from the PARS dataset, see Table 1 for a description. 
Table 4. Participant Index of Knowledge Pre and Post-Seminar

\begin{tabular}{llllll}
$\begin{array}{l}\text { Participant } \\
\text { Characteristic }\end{array}$ & $\mathbf{N}$ & Categories & $\begin{array}{l}\text { Before } \\
\text { Seminar }\end{array}$ & $\begin{array}{l}\text { After } \\
\text { Seminar }\end{array}$ & Difference \\
\hline Full Sample & 840 & & 6.19 & 7.52 & $1.33^{* * *}$ \\
Age & 686 & Ages 50-61 & 6.12 & 7.53 & $1.41^{* * *}$ \\
& 149 & 62 and Over & 6.57 & 7.50 & $0.93^{* * *}$ \\
Gender & 454 & Male & 6.80 & 7.93 & $1.13^{* * *}$ \\
& 386 & Female & 5.48 & 7.04 & $1.56^{* * *}$ \\
Education & 148 & HS or Less & 5.01 & 6.16 & $1.15^{* * *}$ \\
& 682 & Some College & 6.44 & 7.81 & $1.37^{* * *}$ \\
Earnings & 205 & $50 \mathrm{~K}$ or Less & 4.81 & 6.06 & $1.25^{* * *}$ \\
& 630 & More than 50K & 6.64 & 8.00 & $1.36^{* * *}$ \\
Years of Service & 258 & 20 or Less & 6.12 & 7.60 & $1.48^{* * *}$ \\
& 582 & More than 20 & 6.23 & 7.49 & $1.26^{* * *}$ \\
$\begin{array}{l}\text { Self-assessed } \\
\text { knowledge } \\
\text { (scale of 1-7) }\end{array}$ & 480 & Level 1 to 4 & 5.69 & 7.19 & $1.50^{* * *}$ \\
\hline
\end{tabular}

\section{Knowledge Score by Company}

$\begin{array}{lllll}\text { Employer A } & 351 & 5.62 & 7.01 & 1.39^{* * *} \\ \text { Employer B } & 66 & 5.44 & 6.79 & 1.35^{* * *} \\ \text { Employer C } & 156 & 6.87 & 7.46 & 0.59^{* * *} \\ \text { Employer D } & 105 & 7.41 & 8.96 & 1.55^{* * *} \\ \text { Employer E } & 162 & 6.28 & 8.03 & 1.75^{* * *}\end{array}$

Notes: Sample is 840 respondents from the PARS dataset, see Table 1 for a description. Entries in these columns are mean number of questions answered by the participants in each category. ***indicates statistically significant at the $1 \%$ level 
Table 5. Respondents' Retirement Plans Pre- and Post-Seminar

\begin{tabular}{lll} 
& $\begin{array}{l}\text { Survey One } \\
\text { (Before the Seminar) }\end{array}$ & $\begin{array}{l}\text { Survey Two } \\
\text { (After the Seminar) }\end{array}$ \\
\hline
\end{tabular}

Planned Retirement Age: $31.1 \%$ Changed

Median Planned Retirement Age

62

62

Mean Planned Retirement Age

62.3

62.6

Planned Age to Claim Social Security (SS): $36.7 \%$ Changed

Median Age Planned SS Claiming

65

65

Mean Age Planned SS Claiming

64.2

64.5

Plans for Working after Retirement

Expect to Work after Retiring

$$
39.3 \%
$$

$49.4 \%$

Have Not Decided on Working

$36.9 \%$

$26.9 \%$

after Retirement

\section{Annuitization or Lump Sum Distributions}

Planning to Annuitize Some

$19.2 \%$

$26.3 \%$

or all 401(k) Balance

Have Not Decided on Annuitization

$55.7 \%$

$45.4 \%$

of 401(k) Balance

Plan to Take Lump Sum

$26.8 \%$

$24.8 \%$

Distribution of Entire Pension

Have not Decided on Lump Sum

$61.7 \%$

$56.8 \%$

Notes: Sample is 840 respondents from the PARS dataset, see Table 1 for a description. 
Table 6. Changes in Planned Retirement Age Due to Changes in Respondent Knowledge

Any Change

(1)

\section{Panel A:}

Change in Aggregate Knowledge Score (0-10)

Panel B: Changes in...

Public Program - Eligibility (P1, P2, P6)

Public Program - General (P3, P4, P5)

Financial Knowledge Score

Company Specific Knowledge Score

$0.041 * *$

$(0.017)$

$-0.005$

$(0.017)$

$-0.009$

(0.034)

$0.043 *$
Delay

(2)

$\begin{array}{ccc}0.019 * * & 0.017 * * & 0.001 \\ (0.009) & (0.008) & (0.006)\end{array}$

$0.030^{*}$

0.010

$(0.015)$

$(0.011)$

$-0.003$

$-0.003$

(0.015)

(0.010)

0.024

$-0.039 * *$

(0.031)

(0.020)

0.028

0.014

(0.024)

(0.021)

(0.014)

\section{Panel C: Changes in...}

P1: Early Social Security eligibility

$\begin{array}{ccc}-0.039 & -0.039 & -0.002 \\ (0.033) & (0.030) & (0.022) \\ 0.071 * * & 0.064 * * & 0.007 \\ (0.028) & (0.025) & (0.018)\end{array}$

P2: Normal Social Security eligibility

(0.028)

(0.025)

(0.018)

$-0.053 *$

$-0.046^{*}$

$-0.009$

(0.030)

$(0.027)$

(0.018)

0.056

0.024

$0.037 *$

(0.036)

(0.032)

(0.022)

$-0.004$

0.020

-0.031 *

(0.029)

(0.026)

$(0.017)$

$0.083 * * *$

$0.058 * *$

0.026

(0.029)

(0.027)

(0.019)

0.020

0.053

(0.051)

(0.045)

$-0.040$

$-0.036$

0.003

(0.035)

(0.048)

(0.045)

-0.050 *

0.008

0.009

(0.029)

(0.034)

0.070 **

(0.030)

0.039

$-0.006$

(0.033)
(0.021)

0.033

(0.021)

Notes: The sample is 840 respondents from the PARS dataset, see Table 1 for a description. Coefficients are estimated from a probit model and average marginal effects are presented. Each panel consists of three regressions with alternative dependent variables as follows: Column (1) probability of a change in planned retirement age; Column (2) probability of a delay in planned retirement age; and Column (3) probability of earlier planned retirement age. All regressions include controls for age, gender, marital status, tenure, education, earnings, 401(k) account balance, and company fixed effects. Robust standard errors are in parentheses. $* * *$ indicates statistically significant at the $1 \%$ level, ** indicates statistically significant at the $5 \%$ level, and * indicates statistically significant at the $10 \%$ level. 
Table 7. Changes Planned Age to Claim Social Security Due to Changes in Knowledge

\begin{tabular}{|c|c|c|c|}
\hline & $\begin{array}{c}\text { Any Change } \\
(1)\end{array}$ & $\begin{array}{c}\text { Delay } \\
(2)\end{array}$ & $\begin{array}{c}\text { Earlier } \\
(3)\end{array}$ \\
\hline \multicolumn{4}{|l|}{ Panel A: } \\
\hline Change in Aggregate Knowledge Score & $\begin{array}{c}0.038 * * * \\
(0.010)\end{array}$ & $\begin{array}{c}0.018 * * \\
(0.009)\end{array}$ & $\begin{array}{c}0.020 * * \\
(0.007)\end{array}$ \\
\hline \multicolumn{4}{|l|}{ Panel B: Changes in... } \\
\hline Public Program - Eligibility (P1, P2, P6) & $\begin{array}{c}0.084 * * * \\
(0.020)\end{array}$ & $\begin{array}{l}0.033^{*} \\
(0.018)\end{array}$ & $\begin{array}{r}0.051 * * \\
(0.014)\end{array}$ \\
\hline Public Program - General (P3, P4, P5) & $\begin{array}{c}0.013 \\
(0.019)\end{array}$ & $\begin{array}{c}0.017 \\
(0.017)\end{array}$ & $\begin{array}{l}-0.005 \\
(0.012)\end{array}$ \\
\hline Financial Knowledge Score & $\begin{array}{l}-0.013 \\
(0.038)\end{array}$ & $\begin{array}{l}-0.022 \\
(0.033)\end{array}$ & $\begin{array}{c}0.006 \\
(0.028)\end{array}$ \\
\hline Company Specific Knowledge Score & $\begin{array}{c}0.033 \\
(0.026)\end{array}$ & $\begin{array}{c}0.013 \\
(0.023)\end{array}$ & $\begin{array}{c}0.017 \\
(0.016)\end{array}$ \\
\hline \multicolumn{4}{|l|}{ Panel C: Changes in... } \\
\hline P1: Early Social Security eligibility & $\begin{array}{l}-0.013 \\
(0.037)\end{array}$ & $\begin{array}{l}-0.050 \\
(0.034)\end{array}$ & $\begin{array}{c}0.037 \\
(0.026)\end{array}$ \\
\hline P2: Normal Social Security eligibility & $\begin{array}{c}0.151 * * * \\
(0.033)\end{array}$ & $\begin{array}{c}0.108 * * * \\
(0.029)\end{array}$ & $\begin{array}{l}0.045^{*} \\
(0.025)\end{array}$ \\
\hline P3: Benefit reduction at age 62 & $\begin{array}{c}0.027 \\
(0.034)\end{array}$ & $\begin{array}{l}-0.020 \\
(0.030)\end{array}$ & $\begin{array}{l}0.047 * * \\
(0.022)\end{array}$ \\
\hline P4: Permanence of benefit reduction & $\begin{array}{c}0.019 \\
(0.040)\end{array}$ & $\begin{array}{c}0.042 \\
(0.037)\end{array}$ & $\begin{array}{l}-0.030 \\
(0.026)\end{array}$ \\
\hline P5: Social Security indexation & $\begin{array}{l}-0.003 \\
(0.032)\end{array}$ & $\begin{array}{c}0.035 \\
(0.028)\end{array}$ & $\begin{array}{l}-0.033 \\
(0.021)\end{array}$ \\
\hline P6: Medicare eligibility & $\begin{array}{c}0.093 * * * \\
(0.035)\end{array}$ & $\begin{array}{c}0.025 \\
(0.031)\end{array}$ & $\begin{array}{c}0.067 * * * \\
(0.026)\end{array}$ \\
\hline F1: Stock diversification and risk & $\begin{array}{l}0.015 \\
(0.056)\end{array}$ & $\begin{array}{l}-0.017 \\
(0.054)\end{array}$ & $\begin{array}{l}0.033 \\
(0.039)\end{array}$ \\
\hline F2: Inflation and real income & $\begin{array}{l}-0.015 \\
(0.055)\end{array}$ & $\begin{array}{l}-0.012 \\
(0.050)\end{array}$ & $\begin{array}{l}-0.002 \\
(0.037)\end{array}$ \\
\hline $\mathrm{C} 1$ : Eligible for lump sum distribution & $\begin{array}{c}0.026 \\
(0.038)\end{array}$ & $\begin{array}{c}0.007 \\
(0.034)\end{array}$ & $\begin{array}{c}0.017 \\
(0.024)\end{array}$ \\
\hline $\mathrm{C} 2$ : Retiree health insurance & $\begin{array}{c}0.028 \\
(0.037)\end{array}$ & $\begin{array}{c}0.008 \\
(0.033)\end{array}$ & $\begin{array}{c}0.014 \\
(0.025)\end{array}$ \\
\hline
\end{tabular}

Notes: The sample is the PARS data (see Table 1 for a description) further limited to those observations with valid Social Security age responses in both Survey One and Survey Two $(N=728)$. Coefficients are estimated from a probit model and average marginal effects are presented. Each panel consists of three regressions with alternative dependent variables as follows: Column (1) probability of a change in planned age to claim Social Security benefits; Column (2) probability of a delay in planned age to claim Social Security benefits; and Column (3) probability of earlier planned age to claim Social Security benefits. All regressions include controls for age, gender, marital status, tenure, education, earnings, 401(k) account balance, and company fixed effects. Robust standard errors are in parentheses.

$* * *$ indicates statistically significant at the $1 \%$ level, ** indicates statistically significant at the $5 \%$ level, and $*$ indicates statistically significant at the $10 \%$ level. 


\section{Supplemental Data Appendix}

TABLE A-1. PARS and HRS Sample Comparison

\begin{tabular}{|c|c|c|c|c|}
\hline & \multirow[t]{2}{*}{ PARS } & \multicolumn{3}{|c|}{ Health and Retirement Study } \\
\hline & & $\begin{array}{l}\text { Full } \\
\text { Sample }\end{array}$ & $\begin{array}{l}\text { Aged 50-70 } \\
\text { Currently } \\
\text { Employed }\end{array}$ & $\begin{array}{l}\text { Aged 50-70 } \\
\text { Currently } \\
\text { Employed, } \\
\text { Has Pension }\end{array}$ \\
\hline Age & 57.8 & 66.6 & 59.8 & 59.2 \\
\hline Male & $54.1 \%$ & $44.2 \%$ & $46.2 \%$ & $43.3 \%$ \\
\hline Married & $76.3 \%$ & $60.6 \%$ & $64.7 \%$ & $63.4 \%$ \\
\hline Widowed & $2.5 \%$ & $15.9 \%$ & $4.1 \%$ & $1.7 \%$ \\
\hline Years of Service & 24.7 & 11.7 & 11.9 & 12.8 \\
\hline Some College & $82.4 \%$ & $20.1 \%$ & $27.8 \%$ & $31.4 \%$ \\
\hline Own Home & $92.9 \%$ & $83.8 \%$ & $87.0 \%$ & $88.0 \%$ \\
\hline $\begin{array}{l}\text { Years from Planned } \\
\text { Retirement (Before) } \\
\text { Wealth and Earning }\end{array}$ & $\begin{array}{l}4.6 \\
\text { ables: }\end{array}$ & 6.9 & 7.2 & 7.0 \\
\hline $\begin{array}{l}\text { Earnings -- Medium } \\
(\$ 50 \mathrm{~K}-\$ 100 \mathrm{~K})\end{array}$ & $43.6 \%$ & $10.7 \%$ & $2.3 \%$ & $34.7 \%$ \\
\hline $\begin{array}{l}\text { Earnings -- High } \\
(\$ 100 \mathrm{~K}+)\end{array}$ & $31.4 \%$ & $2.8 \%$ & $5.6 \%$ & $9.5 \%$ \\
\hline Financial Literacy & & & & \\
\hline Stock Risk & $84.4 \%$ & $59.2 \%$ & $66.6 \%$ & $69.1 \%$ \\
\hline Inflation & $82.4 \%$ & 79.8 & $83.6 \%$ & $85.5 \%$ \\
\hline Observations & 840 & 1,077 & 314 & 161 \\
\hline
\end{tabular}

Notes: The PARS dataset is described in the text and in Table 1. The Health and Retirement Study sample is from the 2008 RAND HRS Data File. The financial literacy questions were asked in 2004 financial planning module of the HRS. This table presents the mean values for participant response for those that participated in the HRS 2008 survey for comparison to the PARS sample. Some rows vary in sample size due to missing data. Survey weights were used to account for complex survey design.

RAND Data File Citation: RAND HRS Data, Version L. Produced by the RAND Center for the Study of Aging, with funding from the National Institute on Aging and the Social Security Administration. Santa Monica, CA (December 2011). 
Table A-2: Matrix of Planned Retirement Age by Survey

\begin{tabular}{|l|l|l|l|l|l|l|l|l|l|l|l|}
\hline $\begin{array}{l}\text { Planned Age } \\
\text { Before } \backslash \text { After }\end{array}$ & $<62$ & 62 & 63 & 64 & 65 & 66 & 67 & 68 & 69 & 70 & Total \\
\hline$<62$ & 208 & 23 & 3 & 0 & 4 & 2 & 1 & 0 & 0 & 1 & 242 \\
\hline 62 & 13 & 179 & 7 & 4 & 23 & 6 & 1 & 0 & 0 & 1 & 234 \\
\hline 63 & 0 & 6 & 22 & 3 & 3 & 1 & 1 & 0 & 0 & 0 & 36 \\
\hline 64 & 0 & 2 & 3 & 7 & 13 & 0 & 0 & 0 & 0 & 0 & 25 \\
\hline 65 & 2 & 15 & 3 & 2 & 97 & 29 & 5 & 0 & 1 & 4 & 158 \\
\hline 66 & 0 & 0 & 0 & 0 & 6 & 74 & 3 & 0 & 0 & 2 & 85 \\
\hline 67 & 0 & 0 & 0 & 0 & 3 & 8 & 16 & 0 & 0 & 5 & 32 \\
\hline 68 & 0 & 0 & 0 & 1 & 0 & 0 & 1 & 7 & 1 & 5 & 15 \\
\hline 69 & 0 & 0 & 0 & 0 & 0 & 0 & 0 & 0 & 0 & 0 & 0 \\
\hline 70 & 0 & 0 & 0 & 0 & 0 & 0 & 0 & 1 & 0 & 12 & 13 \\
\hline Total & 223 & 225 & 38 & 17 & 149 & 120 & 28 & 8 & 2 & 30 & 840 \\
\hline
\end{tabular}

Notes: The numbers in each cell represent the total number of respondents that had that before/after planned retirement age combination. "Before" ages (Survey One) are by row; "After" ages (Survey Two) are presented in columns. The shaded boxes indicate no change in planned retirement age. The sample is 840 respondents from the PARS dataset, see the text and Table 1 for a description. 
Table A-3: Changes in Planned Retirement Age and SS Claiming Age

\begin{tabular}{|l|l|l|l|l|l|}
\hline & \multicolumn{5}{|l|}{ Planned Retirement Age } \\
\hline & & Earlier & Same & Later & Total \\
\hline \multirow{4}{*}{$\begin{array}{l}\text { Planned SS } \\
\text { Claiming Age }\end{array}$} & Earlier & 24 & 50 & 15 & 89 \\
\cline { 2 - 7 } & Same & 30 & 361 & 62 & 453 \\
\cline { 2 - 7 } & Later & 12 & 88 & 86 & 186 \\
\cline { 2 - 7 } & Total & 66 & 499 & 163 & 728 \\
\hline
\end{tabular}

Notes: The sample is the PARS data (see Table 1 for a description) further limited to those observations with valid Social Security age responses in both Survey One and Survey Two $(N=728)$. The numbers in each cell represent the total number of respondents that had that planned retirement age and planned Social Security claiming age combination. The shaded boxes indicate movement in sync between Social Security claiming age and planned retirement age. "Earlier" indicates a change to an earlier age (i.e., where age as stated on Survey Two is less than the age stated on Survey One). "Same" indicates that the age on Survey One is the same as age on Survey Two. "Later" indicates a change to a later age (i.e., where the age on Survey Two is greater than the age stated on Survey One).

Table A-4: Learning about Normal Social Security Eligibility and Changes in Planned Retirement Age and SS Claiming Age

\begin{tabular}{|l|c|c|c|c|c|}
\hline $\begin{array}{l}\text { Initial } \\
\text { Response }\end{array}$ & $\begin{array}{c}\text { No } \\
\text { Change }\end{array}$ & $\begin{array}{c}\text { Change Retirement } \\
\text { Age Only }\end{array}$ & $\begin{array}{c}\text { Change Social Security } \\
\text { Claiming Age Only }\end{array}$ & $\begin{array}{c}\text { Change } \\
\text { Both }\end{array}$ & $\begin{array}{c}\text { Total in } \\
\text { Category }\end{array}$ \\
\hline Too Low & $40 / 35.4 \%$ & $13 / 11.5 \%$ & $31 / 27.4 \%$ & $29 / 25.7 \%$ & 113 \\
\hline Too High & $28 / 33.8 \%$ & $7 / 8.4 \%$ & $23 / 27.7 \%$ & $25 / 30.1 \%$ & 83 \\
\hline
\end{tabular}

Notes: The sample is the PARS data (see Table 1 for a description) further limited to those observations with valid Social Security age responses in both Survey One and Survey Two $(N=728)$. The numbers in each cell represent the total number of respondents that had the respective planned retirement age and planned Social Security claiming age combination. 